\title{
Constructing the Ideal Future in Foreign Military Media Discourses of The World War II Period
}

\author{
Olga A. Solopova, Maria. S. Saltykova \\ South Ural State University \\ (National Research University) \\ 76, Lenina Av., Chelyabinsk, 454080 Russia
}

\begin{abstract}
The major objective of the paper is to establish functions of modeling the ideal future in the British, American and French military media discourses of World War II period. The authors argue that military media discourse is a hybrid type that combines the components of military, political, military-political, and media discourses whose concentration and interpenetration can vary greatly. The military media discourse is a mode of organizing knowledge, ideas, or experience of war that are rooted in the media and influenced by historical, geopolitical, social, and cultural context. The approach taken in this study is a mixed methodology of linguistic political prognostics that integrates fundamentals of philosophy, future studies, cognitive linguistics, and political linguistics. The samples from the digitized archives of the UK, the USA, and France (24 695 samples) are investigated through a number of methods: corpus, descriptive, cognitive and discourse analyses, cultural, metaphorical modeling, and comparative analyses. Being a basic value of military media discourse, the ideal future is determined by its nature: the idea of a better world inherent in human nature is intensified in transformative moments, war being one of them; representing the present, the media model both the past and the future. The ideal future integrates the key features of utopia and prognosis differing from them in certain specific characteristics. Its basic functions are prognostic, constructive, modeling, critical, provocative, and visualizing ones that complement one another in constructing an ideal projection of the postwar world and the future of the USSR as a geopolitical ally of Great Britain, the USA, and France.
\end{abstract}

Keywords: linguistic political prognostics; military-media discourse; image of the future; discourse format; discourse component; function; World War II; USSR

\section{For citation:}

Solopova, Olga A., Saltykova, Maria S. (2019) Constructing the Ideal Future in Foreign Military Media Discourses of The World War II Period. Russian Journal of Linguistics, 23 (3), 762-783. doi: 10.22363/2312-9182-2019-23-3-762-783. 


\title{
Архитектоника светлого будущего в зарубежных военно-публицистических дискурсах периода Второй мировой войны
}

\author{
О.А. Солопова, М.С. Салтыкова \\ Южно-Уральскй государственный университет \\ (Национальный исследовательский университет) \\ ул. Ленина, 76, Челябинск, 454080, Россия
}

\begin{abstract}
Аннотация
Целью работы является анализ функций моделирования образа светлого будущего в военно-публицистических дискурсах Великобритании, США и Франции периода Второй мировой войны. Авторы считают, что военно-публицистический дискурс представляет гибридный формат, сочетающий компоненты военного, политического, военно-политического и масс-медийного дискурсов, концентрация и взаимопроникновение которых в значительной степени может варьировать. Он складывается в среде массовой коммуникации, соотнесен с военной реальностью, репрезентирует ее и находится под влиянием исторических, геополитических и социокультурных условий, в контексте которых он конструируется и развивается. Исследование выполнено в рамках лингвополитической прогностики, синтезирующей эвристики философии, прогнозирования, когнитивной лингвистики и лингвополитологии. Текстовый материал британского, американского, французского дискурсов (объемом 24695 документов) из оцифрованных архивов Великобритании, США и Франции изучается с использованием комплекса методов: корпусного, описательного, когнитивно-дискурсивного, лингвокультурологического, сопоставительного. Образ светлого будущего как базовая ценность военно-публицистического дискурса детерминирован его природой. Во-первых, стремление к светлому будущему, заложенное в человеческой природе, многократно возрастает и обостряется в условиях переломных и кризисных моментов истории. Во-вторых, создавая и перераспределяя информацию об объективной реальности, медиа не только форматируют настоящее, но и моделируют образы прошлого и будущего. Образ светлого будущего, с одной стороны, вбирает в себя и интегрирует основные черты утопии и прогноза, с другой - обладает специфическими характеристиками, отличными от названных видов проективного знания. К числу его основных функций отнесены прогностическая, конструктивная, моделирующая, критическая, провокативная и визуализирующая функции, которые взаимодополняют друг друга в процессе создания идеальной проекции послевоенного устройства мира и будущего СССР как геополитического союзника Великобритании, Франции, США.
\end{abstract}

Ключевые слова: лингвополитическая прогностика; образ будущего; военно-публичистический дискурс; формат дискурса; компонент дискурса; функиия; Вторая мировая война; СССР

\section{Для цитирования:}

Солопова О.А., Салтыкова М.С. Архитектоника светлого будущего в зарубежных военно-публицистических дискурсах периода Второй мировой войны // Russian Journal of Linguistics. 2019. T. 23. No 3. C. 762 - 783. doi: 10.22363/2312-9182-2019-23-3-762-783.

\section{1. Введение}

Утопия является одной из форм «видения будущего» как альтернативы конструирования иного мира, контрастирующего с настоящим. Нацеленность человека и общества на более совершенную реальность воплощается в виде некоторой мыслительной модели - в образе идеального будущего, то есть суть утопии состоит в проектировании другого мира, противопоставленного окружающей дей- 
ствительности. Причем, в современной философской мысли «иная утопическая реальность» может быть не только ложной и деструктивной, она начинает рассматриваться как феномен, которому присущи конструктивные функции усовершенствования социального порядка (Жданова, Чудова 2011; Тоффлер 2013; Чаликова 1993; Bloch 2000). Будучи созидательной фантазией человечества, связанной с продуцированием общественного идеала, утопия является условием и движущей силой развития культуры и общества (Ainsa 1990).

Категория утопического активно вовлечена в разнообразные сферы социально-философской рефлексии (философия истории, философия культуры, философия политики, социальная философия), что обусловливает актуальность исследования данной категории в военно-публицистическом дискурсе, поскольку данный формат институционального дискурса является междисциплинарной областью, связывающей воедино политику, историю, культуру и медиадискурс.

Утопия представляет собой сложное исторически обусловленное социокультурное явление, продукт общественного сознания, возникающий на определенном этапе развития общества. Исследователи отмечают, что «напряженность» утопизма особенно возрастает в периоды глубоких общественных потрясений (Черткова 1993; Шацкий 1990). Предпосылки утопии заложены в самой сущности дискурса войны и дискурса о войне: двухценностная ориентация военно-публицистического дискурса четко демонстрирует его мифологизированность, в нем условными полюсами редукции являются две альтернативы развития - «победа» и «поражение», и, соответственно, образы будущего (светлого и мрачного) представлены в заостренном виде (Солопова, Чудинов 2018). Образ светлого будущего выполняет функцию посредника между сущим (войной) и должным (победой правых сил, миром), проецируя высшие идеалы и ценности - торжество Справедливости, победу Добра - на действительность.

Моделируемый образ будущего включает в себя целый комплекс аксиологических, философских, исторических, социальных, этнических, когнитивных и собственно лингвистических параметров. Поэтому становится очевидной необходимость глубокого исследования его репрезентации в военно-публицистических дискурсах разных стран с привлечением материала различных хронологических срезов.

В данной статье на материале британского, американского и французского военно-публицистического формата дискурса периода Второй мировой войны будут рассмотрены его особенности и компоненты, с помощью инструментария лингвополитической прогностики будут исследованы функции образа будущего как одной из базовых ценностей военно-публицистического дискурса.

\section{2. Военно-публицистический дискурс как объект дискурсивных исследований}

В современной дискурсологии неоправданно дефицитны комплексные работы, посвященные анализу военно-публицистического дискурса как разновидности дискурса институционального. Тем не менее, необходимые предпосылки для подобного изучения сформировались. Круг наиболее значимых концепций, закла- 
дывающих теоретико-методологические основы исследования военно-публицистического дискурса, формируют работы отечественных и зарубежных ученых по проблематике языковых основ войны (Culpeper 2011, Gavriely-Nuri 2010, Lakoff 1991, Mollin 2018) и конфликтного дискурса (Алешина 2015, Masalha 2003, Starr, Dubinsky 2015). Отдельного внимания заслуживают исследования, затрагивающие специфику военного дискурса (Ищенко 2007, Олянич 2015, Ainsa 1990) и военнополитического дискурса (Бачурин 2014, Солопова, Чудинов 2018, Lakoff 1991). Особый интерес для изучения разрабатываемой тематики представляют работы, направленные на анализ военно-публицистического дискурса (Ищенко 2007, Солопова, Салтыкова 2018, Solopova, Saltykova 2018). Следует подчеркнуть, что проблематика «дискурса войны» и «дискурса о войне» не получила исчерпывающего освещения в современной лингвистической литературе: сохраняет актуальность методологическая проблема соотношения понятий военно-публицистического дискурса, текста, стиля, жанра, отсутствуют определение военнопублицистического дискурса и системное описание структуры и компонентов последнего, не существует четкой дифференциации между военным, военнополитическим и военно-публицистическим видами дискурса.

Одни исследователи включают военно-публицистический дискурс в формат военно-политического дискурса (Бачурин 2014, Солопова, Чудинов 2018). Другие относят его к формату дискурса военного, широкая трактовка которого сводит воедино «дискурс военных о войне, политиков о войне, дискурс средств массовой информации, освещающих военные действия» (Ищенко 2007), «военно-художественную литературу, военную публицистику и военно-политические материалы» (Юсупова 2009). На наш взгляд, это связано с «гибридностью» военно-публицистического дискурса, представляющего собой совокупность компонентов различных институциональных форматов дискурса (военного, военно-политического, политического, массмедийного), концентрация и взаимопроникновение которых в значительных пределах может варьировать.

Данный факт, однако, не исключает возможности условного отграничения военно-публицистического дискурса от смежных с ним феноменов. Опираясь на системообразующие признаки, предложенные В. И. Карасиком для характеристики институционального дискурса (Карасик 2002), можно классифицировать военно-публицистический дискурс как дискурс о войне, агентами которого являются представители СМИ, военные и политические структуры, предоставляющие информацию журналистам, клиентами - непосредственная или имплицированная аудитория. Хронотопом в военно-публицистическом дискурсе в широком смысле могут выступать хронологические рамки и география военного конфликта, отдельного сражения или события, связанного с подготовкой и проведением военных операций, в узком - он определяется временем и местом появления материала в СМИ. Основная цель военно-публицистического дискурса состоит в оказании дифференцированного воздействия на аудиторию, задачи включают массовую мобилизацию населения внутри страны, с одной стороны, и деморализацию противника, с другой. Цель диктует выбор основных стратегий, с помощью которых медиа конструируют смысл событий и образы войны: стратегии презен- 
тации и дискредитации. Военно-публицистический дискурс представлен всем многообразием жанров, свойственных массмедийному дискурсу (аналитическая статья, обозрение, интервью, хроника и другие). Прецедентными текстами, востребованными в военно-публицистическом дискурсе, являются доклады, выступления и обращения политических лидеров государств, глав военных ведомств и международных организаций, с одной стороны, и военно-техническая документация с другой, формирующие военный и военно-политический дискурсы соответственно. Кроме того, ресурсы интертекстуальности включают имена великих полководцев и военачальников, значимые события театра военных действий прошлого, далекого и недавнего. Дискурсивные формулы интегрируют «институциональность» военного дискурса, которая проявляется в военно-фактологической информативности, в употреблении военной терминологии и клише, и «декоративность» массмедийного дискурса, которая состоит в использовании ярких разноуровневых образных средств.

Итак, в нашем понимании, военно-публицистический дискурс является гибридным форматом институционального дискурса, сложивиимся в среде массовой коммуникации, соотнесенным с военной реальностью и репрезентирующчим ее, находящимся под влиянием экстралингвистического контекста (культурно-исторического, идеологического, политического, сочиального). Перефразируя определение Т. ван Дейка (Дейк 2013), военно-публицистический дискурс представляет собой механизм трансформации макросоциального феномена «военный конфликт» на микросоциальный уровень с помощью дифференцированного информационного воздействия, формирующего в сознании аудитории определенные ценностные фрагменты.

\section{3. Инструментарий и материал исследования}

Одной из базовых ценностей военно-публицистического дискурса является образ светлого будущего. Во-первых, как отмечают исследователи, дискурсу средств массовой информации, в принципе, присущи утопические и прогностические свойства (Немирова 2015, Solopova 2017): создавая и перераспределяя информацию об объективной реальности, медиа не только форматируют настоящее, но и моделируют образы прошлого и будущего, присваивая право генерировать как историческое, так и утопическое. Во-вторых, стремление к светлому будущему, заложенное в человеческой природе, многократно возрастает и обостряется в условиях военного конфликта, что предопределено инстинктом самосохранения, позволяющим человечеству выжить и сохранить себя как вид, нацию, государство, т. е. образ светлого будущего детерминирован самой природой военно-публицистического дискурса.

В нашем понимании образ будущего представляет собой наглядное и яркое представление о том, чего нет, но может и могло бы быть, сочетающее рациональное и чувственное, индивидуальное и социальное, языковое и внеязыковое. Образ будущего - это субъективная ментальная репрезентация одного из вероятных миров грядущего, не эквивалентная объектам «внешнего» мира настоящего 
и прошлого: он не может рассматриваться как психическая реакция сенсорного опыта, представленная в сознании как память об этом опыте, поскольку будущее еще не наступило, и не является слепком с настоящей действительности, поскольку будущее предсуществует в настоящем только как предполагаемое или желаемое следствие законов и причинно-следственных связей настоящего, запрограммированных в виде спектра возможных путей развития, или, напротив, как парадоксально непредсказуемые и маловероятные события, наступление которых способно преобразить настоящую реальность.

Вследствие гибридной природы военно-публицистического дискурса и отсутствия в современной дискурсологии специфических методов и приемов его анализа, в настоящей работе предлагается исследовать образ будущего в рассматриваемом формате дискурса с использованием инструментария лингвополитической прогностики, представляющей собой междисциплинарное направление, синтезирующее эвристики философии, прогнозирования, когнитивной лингвистики и лингвополитологии.

Лингвополитическая прогностика постулирует, что прогностичность является имманентной категорией дискурса. Ее универсальность доказана в диахроническом исследовании, проведенном на материале репрезентативных корпусов текстов российского, британского и американского политических дискурсов (Solopova 2017). Один из этапов лингвопрогностического анализа представлен ретроспекцией, результатом которой являются ретроспективные трехуровневые модели будущего. Матричный уровень анализа фокусирует внимание на экстрадискурсивных условиях, существенных для моделирования будущего в том или ином хронологическом срезе, и предполагает изучение совокупности геополитических, культурных, исторических, социальных факторов настоящего, способных оказать влияние на будущее развитие государства и на его конструкт в дискурсе. На интрадискурсивном уровне исследованию подлежат разноуровневые ядерные и периферийные языковые средства с футуральной семантикой. Заключительной процедурой является концептуальный сценарный анализ, представленный двумя предельными альтернативами развития настоящего - мрачным и светлым будущим. Таким образом, инструментарий лингвополитической прогностики соответствует цели и задачам настоящей работы и может быть положен в основу изучения образа будущего в военно-публицистическом дискурсе.

Выбор ретроспективного среза периода Второй мировой войны для анализа образа будущего в зарубежных дискурсах не случаен. Исследовательский интерес обусловлен рядом причин: колоссальными последствиями Второй мировой войны, которые, в частности, привели к формированию современной системы геополитических отношений; переосмыслением официальной концепции истории Второй мировой войны, сформированной советской историографией; появлением новых исследовательских подходов в изучении Второй мировой войны (культурной истории, истории повседневности, гендерной истории, истории памяти), в рамках которых текст рассматривается как исторический источник, отражающий как объективную реальность, так и движущие мотивы и доминантные образы. 
В век цифровых технологий особенности историографии Второй мировой войны заключаются в активном расширении корпуса источников благодаря рассекречиванию архивов, появлению факсимильных баз данных и онлайн собраний военной периодики. В настоящей работе источниками материала для исследования специфики образа будущего в военно-публицистическом дискурсе являются авторитетные архивы исторических газет и журналов Великобритании, США и Франции (The British Newspaper Archive, Chronicling America, Gallica). Использование специализированных систем поиска данных по ключевым словам (будущее, советский, Россия) при условии встречаемости словоформ в пределах одного контекста позволило сформировать иллюстративный корпус текстов на материале каждого дискурса. Результатом процедуры отбора является массив данных за период с 1 сентября 1939 года по 2 сентября 1945 года, включающий 24695 документов британского, американского и французского дискурсов (13 566, 5640 и 5489 документов соответственно) (рис.).

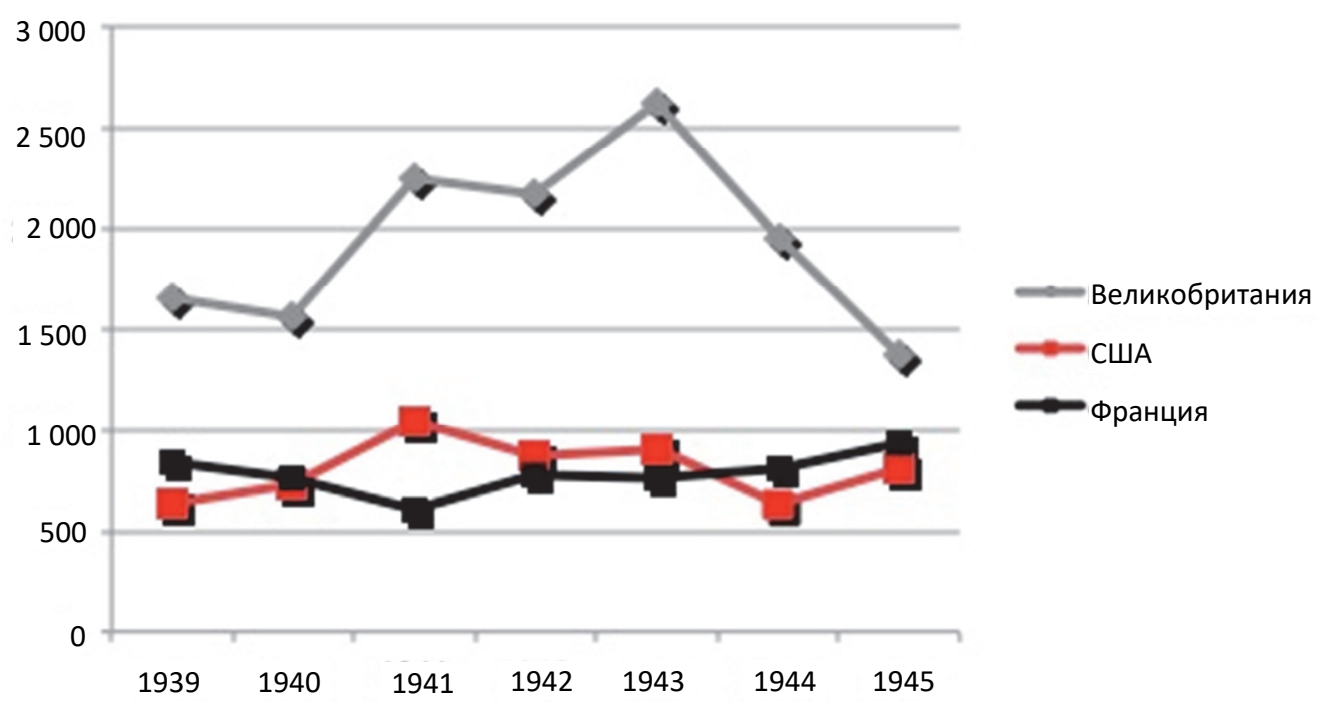

Рис. Данные количественного сопоставительного анализа (1939-1945) /

Fig. Quantitative data of comparative analysis (1939-1945)

Количественный анализ доказывает частотность обращения к проблематике будущего в зарубежных военно-публицистических дискурсах периода Второй мировой войны: каждый хронологический срез (с 1939 года по 1945 год) представлен статистически представительной выборкой документов о будущем СССР в дискурсах Великобритании, США и Франции. Интересно отметить, что интерес будущих стран - участниц «Большой тройки», Великобритании и США, к вероятному развитию событий в Советском Союзе и к роли СССР на международной арене, возрос в год вторжения на его территорию нацистской Германии и ее сателлитов.

Французский дискурс 1941 года, напротив, отмечен наименьшим количеством документов с заданными параметральными данными, что, вероятнее всего, связано 
с установлением во Франции режима Виши: с июля 1940 года тиражи большинства газет сократились в три-четыре раза, многие издания закрылись или были запрещены властями, большая часть оставшихся находилась под контролем службы пропаганды немецкого военного командования. Тем не менее, в последующие годы частотность обращения к образу будущего СССР во французском военнопублицистическом дискурсе возрастает, так как со временем появляются группы движения Сопротивления, начинается выпуск нелегальных изданий, которые также представлены в архиве Gallica.

Не менее показателен численный перевес документов, формирующих подкорпус британского публицистического дискурса в целом, что напрямую зависит от исторической ситуации анализируемого периода, геополитической расстановки сил, целей и установок самой Великобритании, ее взаимоотношений соперничества / союзничества с Советским Союзом (Англо-польский альянс и Польский поход Красной Армии (1939 г.); Советско-финская война (1939-1940 гг.), в которой Великобритания оказывала военную помощь Финляндии; союзничество СССР и Великобритании в борьбе против фашизма (1941-1945 гг.)).

Созданный корпус оцифрованных текстов обрабатывался вручную, поскольку физическое состояние оригинальных источников периода Второй мировой войны осложняет последующую автоматизированную обработку материала и его конвертацию в текстовый формат с помощью профессиональных систем оптического распознавания.

Дальнейшая работа с материалом потребовала привлечения комплекса методов и методик: описательного метода (интепретация, компонентный и контекстуальный анализ), когнитивно-дискурсивного метода (учет экстралингвистического контекста как фактора смыслообразования, интенциональная составляющая военно-публицистического дискурса, его институциональные параметры), метод метафорического моделирования (особенности доминантных метафорических моделей, их прагматические смыслы в моделировании будущего), лингвокультурологического анализа (специфика образа будущего в каждом дискурсе), сопоставительного метода (выявление общих черт и особенностей).

В разделе кратко представлен фрагмент сопоставительного исследования образа светлого будущего в британском, американском и французском военнопублицистических дискурсах. Задачи авторов - показать соотношение «утопического» и «прогностического» в образе светлого будущего в военно-публицистическом дискурсе в целом и продемонстрировать специфику репрезентации будущего СССР как геополитического союзника Великобритании, США, Франции.

\section{4. Функции образа «светлого будущего»: утопия vs прогноз}

Функциональная природа феномена предвидения, его многоаспектность, отвечающая разнонаправленным запросам общества, объясняет его актуальность и востребованность на каждом этапе развития общества. Исследователи отмечают проявление утопической мысли в разные исторические эпохи, выделяя такие функции как критическая, конструктивная, нормативная, прогностическая, провокативная, визуализирующая, мировоззренческая, аксиологическая, моделирующая, 
экспериментальная, поисковая, идеологическая и другие (Черткова 1993). Развитию многовариантного социального воображения способствует появление современных концепций научного прогнозирования - прогностики, футурологии, форсайта, в которых за прогнозом закреплены следующие функции: аналитическая (ретроспективная, диагностическая, прогностическая), поисковая и нормативная, ориентирующая, манипулятивная, управленческая и другие (Агеев 2004).

Каждой из перечисленных функций отведена своя роль в построении проекций культурной и политической сфер жизни общества, социальных движений и катаклизмов (Bloch 2000, Dahrendorf 1967, Duran 1972, Lasky 1976, Tillich 1973). Образ светлого будущего, с одной стороны, вбирает в себя и интегрирует основные черты утопии и прогноза, с другой - обладает специфическими характеристиками, отличными от названных видов проективного знания. Проиллюстрируем ключевые функции моделирования образа светлого будущего в военно-публицистическом дискурсе периода Второй мировой войны.

Потребность человека в предвидении будущего бесспорно согласуется с ролью, выполняемой прогностической функцией. Утопия и прогноз готовят человека и общество к будущему. Утопия ориентирована на предсказание тенденций возможного развития конкретной утопической концепции, т.е. в ней образ светлого (идеального, совершенного, желаемого) будущего является единственной конечной целью. Прогнозирование, в свою очередь, определяет систему альтернатив будущего, фиксирует спектр предполагаемых событий, что порождает многовариантность будущего, т. е. образ светлого (ожидаемого, вероятного) будущего является одним из множества предельных вариантов, противостоящих конечной цели.

В военно-публицистическом дискурсе образ светлого будущего как мира без войны определяется, прежде всего, интересами общечеловеческого порядка. В долгосрочном будущем он состоит в гармонизации отношений между национальными и культурными сообществами, вовлеченными в конфликт, и определяется идеей взаимодополняющего сосуществования и диалога стран, что, так или иначе, соотносится с категорией утопического. В концептуальном плане образы войны и мира выстраиваются на основе бинарной оппозиции тьмы и света. Моделирование светлого будущего сопровождается варьированием и повторами лексем со значением союзничества, сотрудничества, совместности:

(1) In this world war we have come to realise that, in fact, interdependence is more important than independence. The future peace of the world will depend on the cooperation of the United Nations. We have come to know and understand one another as never before in the dark days of war. It is the hope of every man and woman who cares for the future of the world that that knowledge and understanding may grow even more rapidly in the ever-brighten days of peace ${ }^{1}$ (Londonderry Sentinel, 23 November 1943).

1 В этой мировой войне мы поняли, что в действительности взаимозависимость важнее независимости. Будущее мира будет зависеть от сотрудничества Объединенных Наций. В мрачные дни войны мы узнали и поняли друг друга так, как никогда прежде не знали и не понимали. Надежда каждого человека, которого заботит будущее мира, состоит в том, что это знание и понимание будет расти еще быстрее в ясные мирные дни (здесь и далее перевод авторов). 
(2) If there is to be peace in the world, that peace has to be made in full partnership between the English-speaking sea and air power and the massive land power of Russia. The alternative is the loss of the war, chaos after the war and more interminable wars for generations to come ${ }^{2}$ (San Bernardino Sun, 9 June 1942).

(3) Unis dans la guerre et la victoire, ces deux grands pays resteront unis dans la paix pour édifier, aux côtés des autres nations alliées, aux côtés de la France, l'organisation qui garantira aux peuples un avenir de paix et de justice (L'Humanité, 8 november 1944).

Идеальному светлому будущему, лишенному противоречий и конфликтов, свободному от зла и страданий, противостоит не иной вариант грядущего, даже не его зеркальная «мрачная» альтернатива, а продолжение войны, т.е. настоящее. Партнерство великих держав, наличие общего врага и единой высшей цели обусловливает репрезентацию будущего СССР как геополитического союзника в светлом ключе:

(4) I don't think there is any question that if we are victorious, the strongest European Power will be the Soviet Union ${ }^{4}$ (The New York Herald-Tribune, 11 February 1043).

(5) Every reasonable man understands that Russia will play one of the leading roles in the postwar organization of Europe and the whole world ${ }^{5}$ (San Bernardino Sun, 21 July 1943).

(6) L'Union Soviétique est une grande nation. Son peuple est un grand peuple qui, dans l'avenir, doit jouer un rôle que l'on peut mesurer aux réussites déjà réalisées ${ }^{6}$ (Russie d'aujourd'hui, juin 1943).

Причем, следует особо подчеркнуть, что Советскому Союзу безоговорочно отводится ведущая роль как в период военных действий, так и в послевоенном мироустройстве:

(7) Future of any race will be determined in Russia ${ }^{7}$ (Portsmouth Evening News, 30 March 1942).

(8) The war will be decided in Russia anyway ${ }^{8}$ (San Bernardino Sun, 23 December 1942).

2 Если наступит мир, то этот мир должен быть заключен при полном партнерстве между англоговорящими морскими и воздушными державами и огромной сухопутной державой, Россией. Единственной альтернативой является поражение в войне, хаос после войны и бесконечные войны в будущем.

3 Объединивиись в войне и в победе, эти две великие державы (СССР и США - прим. авт.) останутся едиными в мире, чтобы вместе с Францией и другими странами-союзницами построить систему, которая обеспечит народам будущее в мире и справедливости.

4 Не думаю, что существуют сомнения в том, что в случае нашей победы самой мощной европейской державой будет Советский Союз.

5 Каждый думающий человек осознает, что Россия будет играть одну из ведущии ролей в послевоенном устройстве Европы и всего мира.

${ }^{6}$ Советский Союз - великая держава. Ее народ - великий народ, который в будущем должен играть ту роль, которую можно оценить по уже достигнутыл победам.

7 Будущее каждого народа будет определено в России.

8 Исход войны в любом случае будет предрешен Россией. 
(9) L'Union Soviétique apparaît aujourd'hui aux yeux de tous comme l'une des plus grandes puissances du monde. Ses pires ennemis d'hier reconnaissent volontiers désormais qu'elle a sauvé l'univers, la civilisation moderne, tout l'avenir humain ${ }^{9}$ (L'Humanité, 8 november 1944).

Узловой точкой, в которой пересекаются утопия и образ будущего в военнопублицистическом дискурсе, является не только проспективность, но и формирование идеального конструкта будущего, что достигается за счет конструктивной и моделирующей функций. Процесс создания совершенной модели - синтез фактов, внесение новизны и провоцирование ментальных усилий - позволяют определить желаемый образ и исключить другие альтернативы. В идеальном светлом будущем заложено стремление к миру, воля к победе, надежда на торжество добра, на освобождение от тягот и лишений войны. При этом конструкты будущего могут быть отнесены к краткосрочной и долгосрочной перспективе, высшей целью которых являются победа над фашизмом и совершенное устройство послевоенного мира соответственно:

(10) Friendship with the Soviet Union and close co-operation in future would bring nearer to realization that great ideal of mankind, permanent and enduring peace ${ }^{10}$ (The Lancaster Guardian, 3 December 1943).

(11) We must fight with a full heart, for the destruction of the enemy, his complete annihilation, the wiping of Hitlerism forever from the face of the earth. We must strengthen the Anglo-Soviet-American Alliance in the fires of war so that it will be an indestructible instrument for a desired peace ${ }^{11}$ (Evening Star, 25 February 1943).

(12) La France et l'U.R.S.S. doivent rester unies «dans le présent pour écraser le fascisme, dans l'avenir pour construire une paix durable». Une séparation entre l'U.R.S.S. et nous ne doit jamais se produire, car le progrès, la paix et le bonheur de l'humanité en dépendent ${ }^{12}$ (L'Humanité, 18 décembre 1944).

Победа над противником является конечной целью в военном конфликте и идеальным образом в военно-публицистическом дискурсе. Она представляет собой стержневой элемент светлого будущего, ориентирующий геополитических союзников на поиск конструктивных моделей мирового устройства в послевоен-

9 Сегодня все признают Советский Союз одной из величайших держав мира. Его вчерашние злейшие враги отныне добровольно признают, что СCCP cпас весь мир, всю современную цчивилизацию и будущеее человечества.

10 Дружба с Советским Союзом и тесное сотрудничество в будущем приблизят к достижению великого идеала человечества, к наступлению долговременного и прочного мира.

11 Мы должны сражаться всем сердцем за уничтожение врага, за его полное истребление, мы должны навсегда стереть фашизм с лица земли. Мы должны укрепить англо-советско-американский альянс на огневом рубеже так, чтобы он стал нерушимым инструментом в условиях желанного мира.

12 Франция и Советский Союз должны оставаться едиными «в настоящем, чтобы подавить фашизм, в будущем - чтобы построить прочный мир». Никогда не должно произойти раскола между СССР и нами, поскольку от этого зависят прогресс, мир и счастье человечества. 
ный период. Образ «будущего» послевоенного мира задает идеальную проекцию геополитической системы, что также максимально сближает его с утопией:

(13) If history records Hitler as having been of any use whatever to the world, it will be because he destroyed the distrust which had formerly existed between Soviet Russia and the rest of the civilised world, and so opened the way to a new and more hopeful organisation of international security ${ }^{13}$ (Liverpool Daily Post, 21 June 1943).

(14) The alternative is genuine economic and political collaboration among equal sovereign states, envisaged in the scraps of paper which made up the Atlantic Charter and the Moscow declaration. The American people have taken the principles of both of these documents seriously ${ }^{14}$ (Sunday Star, 14 January 1945).

(15) L'Armée de l'U.R.S.S. a rempli magnifiquement sa mission historique en défendant la patrie soviétique menacée et envahie par la sauvagerie hitlérienne. Elle a en même temps contribué, plus que nulle autre force au monde, là, libérer tous les pays démocrates antifascistes asservis par Hitler ou menacés par lui d'asservissement. Par ses sacrifices sans nombre, l'U.R.S.S. a assuré leur liberté de demain et leur sécurité internationale pour l'avenir ${ }^{15}$ (Journal officiel de la République française, 22 décembre 1944).

Замысел построения разумного социального порядка в мире геополитики, проект идеального сообщества, в котором возможно гармоничное и мирное сосуществование идеологических и социальных моделей, опирающихся на разнородные культурные и мировоззренческие, - суть утопических установок военнопублицистического дискурса периода Второй мировой войны.

Конструктивный потенциал образа будущего и аксиологический аспект его светлой альтернативы выступают той идеальной детерминантой, с которой соотносятся и критически осмысливаются настоящее и прошлое. В военно-публицистическом дискурсе критическая функция проекции в будущее - это, прежде всего, отрицание существующей действительности и стремление заменить ее безупречно сконструированной моделью идеального послевоенного мира. В отличие от прогнозирования, где альтернативы будущего экстраполируются из устойчивых тенденций настоящего и прошлого, в моделировании светлого образа послевоен-

13 Если в анналах истории и будет отмечена какая бы то ни было польза, принесенная миру Гитлером, то она будет состоять в том, что он уничтожил недоверие, ранее существовавшее между Советской Россией и остальным цивилизованным миром, и этим открыл путь к новой, многообещающей организачии международной безопасности.

14 Альтернативой этому является истинное экономическое и политическое сотрудничество между равными суверенными государствами, предусмотренное в Атлантической хартии и Московской декларации. Народ Америки серьезно воспринял принципы, изложенные в этих документах.

15 Советская армия великолепно выполнила свою историческую миссию, защищая Родину, находящуюся под угрозой и захваченную гитлеровским зверем. Больше, чем любая другая держава в мире, она способствовала освобождению всех антифашистских демократических стран, порабощенных Гитлером или находящихся под угрозой гитлеровского порабощения. Благодаря своим бесчисленным жертвам СССР обеспечил их завтрашнюю свободу и международную безопасность в будущем. 
ного мира отчетливо проявляются черты утопии. Он выстраивается как антитеза настоящему: идеальное будущее противопоставляется мрачному и непотребному настоящему, мир мыслится как избавление от абсолютного зла, хаоса, лишений войны (настоящее) и торжество абсолютного добра, наступление порядка и всеобщего благополучия (будущее):

(16) We want an end to the cruelty and destructiveness of war - we want in its place a new beginning - a beginning of sure and true peace ${ }^{16}$ (The Scotsman, 26 April 1945).

(17) The purpose is to continue to build the foundation for an international accord which will bring order and security after the chaos of war, and which will give some assurance of lasting peace among the nations of the world ${ }^{17}$ (The Wilmington Morning Star, 2 March 1945).

(18) C'est le sentiment obsédant de ces immenses sacrifices consentis, là-bas et partout où les hommes de bonne volonté ont dû défendre chèrement leur liberté qui nous dicte la tâche à accomplir : faire une Europe en ordre pour avoir une Europe en paix $^{18}$ (Journal officiel de la République française, 22 november 1944).

Наиболее отчетливо специфика критической функции прослеживается при моделировании образа светлого будущего СССР как геополитического союзника Великобритании, США и Франции. В этом образе, с одной стороны, заложено неразрывное единство будущего, настоящего и прошлого, типичное для прогнозирования, с другой - свойственные утопии инверсия исторического времени и обратный порядок связи времен. То есть время течет из будущего через настоящее в прошлое. В отличие от утопии образ светлого будущего геополитического союзника не отрицает настоящего и породившего его прошлого, напротив, он встраивает их в контекст светлой альтернативы и форматирует матрицу смыслов, значений, событий в нужном ключе. То есть именно будущее определяет настоящее и прошлое:

(19) The U.S.S.R. itself has by no means reached finality in constitution building. The present stretch of its road to democracy lies through a period of peaceful evolution towards that personal liberty which is the hallmark of democracy. Russia seeks peaceful relations with all States irrespective of their political systems, economic and political co-operation, alliances against aggression, renunciation of imperialist expansion at the cost of other nations ${ }^{19}$ (Western Mail, 18 November 1944).

16 Мы хотим положить конец жестокости и разрушительности войны. Вместо нее мы хотим начала новой жизни - начала надежного и настоящего мира.

17 Цель состоит в том, чтобы продолжать выстраивать основу для международного согласия, которое после хаоса войны принесет порядок и безопасность и которое гарантирует прочнылй мир между народами мира.

18 Неотступная мысль об огромных жертвах всюду, где люди доброй воли были вынуждены заплатить высокую цену за свою свободу, диктует нам задачу: привести Европу в порядок, сделать так, чтобы она существовала в мире.

19 СССР еще не достиг завершенности в создании конституции. Нынешний этап его пути к демократии лежит через период мирной эволюции к личной свободе, которая является отличительной чертой демократии. Россия стремится к мирным отношениям со всеми государствами вне зависимости от их политического устройства, к экономическому и политическому сотрудничеству, к союзам против агрессии, к отказу от империалистической экспансии за счет других государств. 
(20) The Union of Soviet Socialist Republics is so much the foremost champion of all the democratic forces of Europe that the United States, our country, which for a century and a half stood in the vanguard of world democracy, can now be allied with those democratic forces in Europe ONLY ON CONDITION ${ }^{20}$ that we are allied with the Soviet Union ${ }^{21}$ (Western Daily Press, 10 February 1942).

(21) La France d'aujourd'hui est sûre qu'on lui a grossièrement menti! Elle voit en U.R.S.S. un peuple uni, fort, un peuple qui sait souffrir, qui sait lutter, qui sait vaincre. Elle ne peut plus nier que les chefs de l'Union Soviétique comptent parmi les meilleurs directeurs d'Etats des temps actuels ${ }^{22}$ (L'Echo d'Alger, 30 décembre, 1944).

Негативные тенденции в моделировании образа Советского Союза, типичные для зарубежных дискурсов довоенного периода (неприятие советского режима, боязнь «красного террора» и распространения коммунистической «заразы», возможность экономической, научно-технической и военной угрозы со стороны (ССР), коренным образом трансформируются в военно-публицистических дискурсах периода Второй мировой войны при репререзентации образа светлого будущего СССР, сильного союзника, основной военно-политической силы, обусловливающей победный ход войны. Демократия и коммунизм как две различные идеологии более не противостоят друг другу: «демократичность» коммунистического режима интерпретируется как данность, то есть нечто представленное в действительности, и как задание на будущее, которое подлежит дальнейшему воплощению в жизнь. За советским режимом признается право на существование, констатируется «законность» социально-политического устройства Советского Союза, прочность и результативность власти, величие Советов:

(22) Scotland is going to gain, in following in the path that Russia had set before us, far more in the way of democracy, as well as in breaking up Britain into a number of free states on the plan of the U.S.S.R. ${ }^{23}$ (Stirling Observer, 29 June 1943).

(23) The Soviet people have built a great government. They are a great people or they could not have built a great government. I have the greatest possible admiration for the Russian people as a people ${ }^{24}$ (Evening Star, 25 September 1942).

${ }^{20}$ Сохранено шрифтовое выделение оригинального текста (прим. авт.).

21 Союз Советских Социалистических Республик является первостепенным приверженцем и поборником демократии среди всех демократических сил Европы, Соединенные Штаты, наша страна, которая на протяжении полутора веков стояла в авангарде мировой демократии, сейчас может быть в союзе с демократическими силами Европы ТОЛЬКО ПРИ УСЛОВИИ союзничества с Советским Союзом.

22 Сегодня Франция уверена, что вчера ее обманули! Она видит, что Советский Союз единый, сильный народ, народ, который знает, как страдать, как бороться, знает, как победить. Она больше не может отрицать тот факт, что лидеры Советского Союза - одни из лучших государственных руководителей этого времени.

23 Шотландия станет значительно более демократическим государством, следуя по пути, который открыла перед нами Россия и создав на территории Великобритании несколько свободных государств по образцу СССР.

24 Советский народ создал великое правительство. Это великий народ, иначе он не смог бы создать великое правительство. Я испытываю величайшее восхищение русским народом. 
(24) Nul ne peut plus contester qu'ils ont placé leur peuple naguère arriéré à la tête des pays les plus évolués! $!^{25}$ (L’Echo d'Alger, 30 décembre 1944).

Более того, сконструированное согласно проекции светлого будущего настоящее предлагает новые возможности и пути совершенствования государственного устройства не только самого Советского Союза, но и иных государств: СССР представляет собой модель идеального социалистического строя и выступает образцом для подражания.

Образ светлого будущего, ожидающий геополитического союзника в перспективе, проецируется на представление о его руководителях, ответственных как за ее будущее, так и за настоящее, превративших страну в мощную промышленную и военную державу, которая способна одержать победу в битве с фашизмом:

(25) Stalin is the greatest military strategist of this war, surpassing even Montgomery, and the future of the peoples of the world depends on the people of Soviet Russia and Great Britain ${ }^{26}$ (Rochdale Observer, 3 March 1945).

(26) All history contains nothing to compare with the mighty deeds of the Red Army under the guiding genius of Stalin. They have turned the tide of war definitely in favor of the United Nations. They have brought victory within reach ${ }^{27}$ (Evening Star, 25 February 1943).

(27) Les chefs des nations alliées, comme les autorités morales et intellectuelles les plus hautes rendent hommage au peuple soviétique, à son Armée Rouge qui a porté le coup mortel au fascisme barbare, à Staline, chef de la politique et de la stratégie de l’U.R.S.S. ${ }^{28}$ (L'Humanité, 18 décembre 1944).

Инверсия времени и ориентация на светлое будущее структурируют прошлое геополитического союзника, которое оценивается и форматируется, исходя из успехов и побед в настоящем и из перспективы плодотворного и взаимовыгодного сотрудничества в будущем:

(28) Had the Soviet leaders not carried out their task magnificently these 25 years, many people who are in this room might to-night have been in concentration camps, if they were still alive $^{29}$ (The Surrey Mirror, 27 November 1942).

(29) There is deep significance for today in the fact that we combine in this meeting the commemoration of Abraham Lincoln, America's foremost contribution to the world leadership of democratic liberation, and of Vladimir Ilyich Lenin, founder of the Soviet

${ }^{25}$ Никто не может более оспаривать тот факт, что Советский Союз, который не так давно считался слаборазвитым государством, направил свой народ в авангард самых развитых стран!

${ }^{26}$ Сталин - величайший военный стратег этой войны, превосходящий даже Монтгомери, будущее народов мира зависит от народов Советской России и Великобритании.

27 Вся история не сравнится с невероятными победами Красной Армии, ведомой гением Сталина. Определенно, они переломили ход войны в пользу Организации Объединенных Наций. Они сделали победу досягаемой.

28 Лидеры союзных наций воздают должное советскому народу, его политическому лидеру Сталину, и Красной Армии, которая нанесла смертельный удар по варварскому фашизму.

${ }_{29}$ Если бы советские лидеры блестяще не выполняли свою задачу эти 25 лет, многие люди, которые находятся здесь, могли бы быть в концентрационных лагерях, если бы были еще живы. 
Power which at this moment is liberating the world from the menace of Nazism ${ }^{30}$ (Evening Star, 25 February 1943).

(30) C'est que deux années de lutte sur le front oriental, la magnifique résistance de l'Armée Rouge, la victoire de Stalingrad, la puissance grandissante de l'Union Soviétique ont prouvé jusqu'à l'évidence que la Russie n'était pas telle que la dépeignaient ses adversaires $^{31}$ (Russie d'aujourd'hui, juin 1943).

Образ общей цели, роль СССР в ее достижении позволяют сближать разные системы государственного устройства и нивелировать идеологические противоречия прошлого. Мыслимое общее светлое будущее заставляет искать и находить схожие черты между собственной страной и социалистической Россией в настоящем и в прошлом, оценивать пройденный советским государством путь с точки зрения его заслуг в настоящем и моделируемом будущем.

В ситуации военного времени глобальная проблема установления и сохранения мира, идея служения Отечеству и обеспечения безопасности государства, «придают смысл существованию, становятся стимулом великих свершений» (Асабина 2009) и мощным рычагом мобилизации общественных масс. И утопия, и прогноз, как формы проективного знания, ориентированы на поиск проблемных узлов в настоящей действительности и формирование новых ракурсов возможного устройства мирового сообщества. В военно-публицистическом дискурсе е д и н с т в е н ны м предпочтительным и нормативным вариантом будущего развития военного конфликта, принимаемым в качестве цели, является победа. Провокативная функция образа светлого будущего, реализуемая в форме призыва или указания, призвана стимулировать рефлексию адресата и каузировать выполнение действия по изменению социальной реальности:

(31) You must think victory, and then you must act victory ${ }^{32}$ (Stirling Observer, 29 June 1943).

(32) Achievement of victory over Hitlerism - is the supreme common task today. In the name of Lincoln and Lenin we devote all our capacities to that goal ${ }^{33}$ (Evening Star, 25 February 1943).

(33) Et, après la victoire, ce qu'il faudra faire pour que cette victoire ne soit pas vaine, nous le ferons en commun; sans tergiverser, sans attendre, toutes les mesures seront prises, parce que nous savons ce que nous a coûté une position naguère hésitante ${ }^{34}$ (Journal officiel de la République française, 22 décembre 1944).

30 Сегодня имеет большое значение то, что на этом собрании мы чтим память об Аврааме Линкольне, чей вклад в мирвое лидерство Америки в борьбе за демократическое движение является самым выдающимся, и о Владимире Ильиче Ленине, основателе советской державы, которая в данный момент освобождает мир от угрозы нацизма.

31 Два года борьбы на восточном фронте, мощное сопротивление Красной Армии, победа Сталинграда, растущуее величие Советского Союза доказали, что Россия оказалась не тем государством, каким бы ее хотели представить противники.

32 Ты должен думать только о победе и делать все для победы.

33 Сегодня победа над гитлеризмом - это общая высшая цุель. Во имя Линкольна и Ленина мы посвящаем все наши силы достижению этой цели.

34 И когда мы победим, необходимо сделать так, чтобы эта победа не была напрасной, мыл осуществим это вместе; будут приняты все меры, не откладывая, не дожидаясь, потому что мы знаем, чего стоило нам занять нерешительную позицию. 
Рассматриваемая функция ведет не только к преодолению шаблонов и сложившихся стереотипов, но и к изменению отношения к социальной действительности в целом и к образу геополитического союзника в частности:

(34) Plan the future with Russia now ${ }^{35}$ (Portsmouth Evening News, 17 March 1943).

(35) Listen, America, Russia happens to be fighting our battles now and fighting them with success. We must not forget that the heroism of Russians and their brilliant victories over Hitler have saved us and given us the breathing spell we need. Beware of those belittling or degrading Russia ${ }^{36}$ (Roanoke Rapids Herald, 26 February 1942).

(36) Pour la France et la Russie, être unies c'est être fortes; se trouver séparées, c'est se trouver en danger ${ }^{37}$ (Journal officiel de la République française, 22 décembre 1944).

Образ светлого будущего способствует обновлению системы ценностей, норм, геополитических и социальных ориентиров адресата, выполняя роль своеобразного катализатора мышления и мотиватора, побуждающего к сотрудничеству с Советским Союзом и мобилизации совместных усилий к достижению желаемого результата.

Одной из основных в процессе конструирования образа светлого будущего в военно-публицистическом дискурсе является визуализирующая функция, в принципе присущая утопии. Ее роль состоит в осмыслении социокультурного идеала, в его воплощении в образах и символах, что содействует моделированию целостной, осязаемой картины светлого будущего. В процессе создания системы образов, наиболее развернуто репрезентирующих светлое будущее, особенно активна когнитивная метафора:

(37) Russia, stubbornly defending herself, had shown a strength and resilience which might well make her one of the architects of the future ${ }^{38}$ (Yorkshire Evening Post, 12 November 1941).

(38) Russia will probably be the most powerful single star in the world if, with the help Britain and the United States, she is able to smash Germany ${ }^{39}$ [Evening Despatch]. Friends for Tomorrow. In peacetime we'll need the friendship of our Allies as much as we do now, in war. Whatever our views may be about communism, Russia stands today as the Savior of democracy in Europe ${ }^{40}$ (Evening Star, 14 February 1943).

${ }^{35}$ Планируй будущеее с Россией.

${ }^{36}$ Послушай, Америка, Россия сейчас сражается в наших битвах и сражается успешно. $M b l$ не должны забывать, что героизм русских и их блестящие победы над Гитлером спасли нас и дали нам необходимую передышку. Берегись тех, кто принижает заслуги России и подрывает ее авторитет.

37 Для Франции и России быть в единстве - оставаться сильными; быть врозь оказаться в опасности.

38 Стойко обороняющаяся Россия проявила силу и неустрашимость, что вполне может превратить ее в одного из архитекторов будущего.

39 Вероятно, Россия будет самой яркой и единственной звездой в мире, если с помощью Великобритании и США ей удастся разгромить Германию.

40 Друзья завтрашнего дня. В мирное время нам будет так же сильно нужна дружба наших союзников, как сейчас, во время войны. Что бы мы ни думали о коммунизме, сегодня Россия является Спасителем демократии в Европе. 
(39) Le Secours Populaire de France et des Colonies affirme, avec l'unanimité des Français que l'union avec la grande démocratie soviétique permettra d'aller, suivant la belle phrase rappelée par Gabriel Péri quelques instants avant sa mort «vers des lendemains qui chantent» ${ }^{41}$ (La Défense, 22 décembre 1944).

Востребованность метафоры в конструировании образа светлого будущего определяется рядом причин. Во-первых, как утопия и прогноз, она является специфической формой освоения окружающего мира, и ей присущи те же самые функции. Во-вторых, она представляет собой базовый механизм познания и категоризации различных модусов действительности, в том числе будущего. В-третьих, структура метафоры (X подобно Y) дает возможность радикально сократить путь от одного образа к другому, что позволяет экономно, четко и ярко представить новое знание применительно к новым условиям, но отталкиваясь от уже известного и знакомого. В-четвертых, в метафорах заложены те ключевые образы и символы, которые позволяют интенсифицировать двухценностную ориентацию военно-публицистического дискурса (свет - тьма, ад - рай, добро - зло, друг враг, строительство - разрушение и другие). В-пятых, образ светлого будущего, его миросозидательные установки предопределяют и объясняют использование определенных метафор контекстом военно-публицистического дискурса (метафоры родства, строительства, религии, дома и другие), что свидетельствует об их взаимообусловленности и взаимозависимости.

\section{5. Заключение}

Образ светлого будущего является одной из базовых ценностей военно-публицистического дискурса. Он интегрирует и модифицирует функции утопии и прогноза, перерабатывая их в соответствии со спецификой рассматриваемого формата дискурса и выбранного для анализа исторического периода. Как любой форме проективного знания образу светлого будущего в военно-публицистическом дискурсе свойственны следующие черты:

- его отражение и репрезентация в текстах анализируемого временного периода: образ светлого будущего является идеальной проекцией того общества и того исторического момента, в котором он возник, что обусловливает его востребованность обществом как формы сознания, выражающего альтернативность развития истории (прогностическая функция);

- значимость образа будущего для исторического момента, поскольку в нем аккумулируются идеалы, надежды и чаяния представителей не одного, а различных сообществ (моделирующая и конструктивная функции);

- связь с настоящим и отрицание последнего в случае моделирования образов войны и послевоенного мира, переформатирование настоящего и прошлого геополитического союзника в соответствии с представлением о его вероятном будущем (критическая функция);

41 Организация Народная Помощь Франции и Колоний в единстве с французским народом утверждают, что союз с великой советской демократией позволит прийти, как красиво сказал Габриэль Пери за несколько минут до смерти, к идеальному будущему (досл. «к завтрашним дням, которые поют»). 
- незавершенность, когнитивная составляющая которой заключается в побуждении к дальнейшей рефлексии над будущим, а апеллятивная - в призыве к активным действиям, направленным на изменение существующего миропорядка и способным перенаправить развитие истории (провокативная функция);

- метафоричность и экспрессивность: создание системы образов, наиболее развернуто репрезентирующих идеальную альтернативу (визуализирующая функция).

С одной стороны, образы светлого будущего послевоенного мироустройства и СССР как геополитического союзника в британском, американском и французском военно-публицистических дискурсах способствовали целенаправленной реализации общих ориентиров в достижении единой цели - победы над фашизмом. С другой стороны, они являлись «сиюминутными» утопиями, порожденными конъюнктурой военного времени, потребовавшей союзничества столь разных систем идеологического и общественного мироустройства. Плодотворное сотрудничество Советского Союза в мире послевоенной геополитики с его бывшими соратниками по оружию осталось незавершенным проектом мировой истории, как и утопическая концепция «мира во всем мире».

(C) О.А. Солопова, М.С. Салтыкова 2019 cc) creative

https://creativecommons.org/licenses/by/4.0/

\section{ФИНАНСИРОВАНИЕ И БЛАГОДАРНОСТИ}

Исследование выполнено при поддержке РФФИ (проект № 19-012-00192).

\section{FINANCE AND ACKNOWLEDGEMENTS}

The research done for this work has been funded by RFBR (project № 19-012-00192).

\section{СПИСОК ЛИТЕРАТУРЫ / REFERENCES}

Агеев А. И. Энергия будущего // Экономические стратегии. М.: ИНЭС, 2004. №8. С. 1-5. [Ageev, Aleksandr I. (2004). Energiya budushchego. (The Energy of the Future). In Ekonomicheskie strategii. Moscow: INES, 8, 1-5. (In Russ.)].

Алешина Е.Ю. Публичный политический дискурс конфликтной ситуации. М.: Прометей, 2015. 220 c. [Aleshina, Ekaterina Yu. (2015). Publichnyi politicheskii diskurs konfliktnoi situatsii (Public Political Discourse in Situations of Conflict). Moscow: Prometei. (In Russ.)].

Асабина Т.Ю. Утопия в исторической перспективе // Труды Белор. гос. технич. ун-та. Cер. V. Политология, философия, история, филология. 2009. Вып. XVII. C. 104-106. [Asabina, Tatiana Yu. (2009). Utopiya v istoricheskoi perspektive (Utopia through history). In Trudy Belorusskogo gosudarstvennogo universiteta. Series "Politologiya, filosofiya, istoriya, filologiya", 17, 104-106. (In Russ.)].

Бачурин В.Д. Манипулятивные технологии, применяемые СМИ в современном военно-политическом дискурсе // Политическая лингвистика / под ред. А.П. Чудинова. Екатеринбург, 2014. № 4 (50). C. 99-104. [Bachurin, Vadim D. (2014). Manipulyativnye tekhnologii, primenyaemye SMI v sovremennom voenno-politicheskom diskurse [Manipulative Technologies Used in Modern Military Media and Political Discourse by Mass Media]. In Politicheskaya lingvistika. In Chudinov, A.P. (ed.). Yekaterinburg, 4 (50), 99-104. (In Russ.)]. 
Дейк Т. ван. Дискурс и власть: репрезентация доминирования в языке и коммуникации / пер. с англ. Е.А. Кожемякин, Е.В. Переверзев, А.М. Аматов. М.: Либроком, 2013. 344 с. [Dijk, Teun A. van. (2013). Diskurs $i$ vlast': reprezentatsiya dominirovaniya v yazyke i kommunikatsii [Discourse and Power. Contributions to Critical Discourse Studies]: transl. by E.A. Kozhemyakin, E.V. Pereverzev, A.M. Amatov. Moscow, Librokom. (In Russ.)].

Жданова С., Чудова И.А. Идеологии и утопии современного общества: визуальный анализ кинотекста // Современный дискурс-анализ. 2011. № 1 (4). С. 51-71. [Zhdanova, Sofia, Chudova, Irina A. (2011). Ideologii i utopii sovremennogo obshchestva: vizual'nyi analiz kinoteksta [Ideologies and Utopias of Modern Society: Image Analysis of the Film Construct]. In Sovremennyi diskurs-analiz, 1 (4), 51-71. (In Russ.)].

Ищенко Н.А. Военный дискурс и дискурсивное измерение войны // Культура народов Причерноморья. 2007. № 116. C. 22-24. [Ishchenko, Natalia A. (2007). Voennyi diskurs i diskursivnoe izmerenie voiny [Military Discourse and Discursive Measuring of War]. In Kul'tura narodov Prichernomor'ya, 116, 22-24. (In Russ.)].

Карасик В.И. Языковой круг: личность, концепты, дискурс. Волгоград: Перемена, 2002. 477 с. [Karasik, Vladimir I. (2002). Yazykovoi krug: lichnost', kontsepty, diskurs [Linguistic Framework: Personality, Concepts, Discourse]. Volgograd, Peremena. (In Russ.)].

Немирова Н.В. Прецедентность политического прогнозирования в газетном дискурсе // Политическая лингвистика / под ред. А.П. Чудинова. Екатеринбург, 2015. № 3 (53). С. 148 155. [Nemirova, Natalia V. (2015). Pretsedentnost' politicheskogo prognozirovaniya $\mathrm{v}$ gazetnom diskurse [Precedential Character of Political Prediction in Newspaper Discourse]. In Politicheskaya lingvistika. In Chudinov, A.P. (ed.). Yekaterinburg, 3 (53), 148-155. (In Russ.)].

Олянич А.В. Милитарный (военный) дискурс // Дискурс-Пи. Т. 12. Екатеринбург: Дискурс-Пи, 2015. № 2. C. 165-167. [Olyanich, Andrey V. (2015). Militarnyi (voennyi) diskurs [Military Discourse]. In Diskurs-Pi, 12, 2, 165-167. (In Russ.)].

Солопова О.А., Салтыкова М.С. Битва прошлого, битва за прошлое: «Курская Дуга» в военнопублицистическом дискурсе союзников // Взаимодействие языков и культур: мат-лы междунар. науч. конф. Челябинск: ЮУрГУ, Т. 1. 2018. С. 135-139. [Solopova, Olga and Saltykova, Maria (2018). Bitva proshlogo, bitva za proshloe: "Kurskaya Duga" v voennopublitsisticheskom diskurse soyuznikov (The Battle of the Past, the Battle for the Past: "Kursk Salient" in Military-Media Discourse of the Allies). In Vzaimodeistvie yazykov i kul'tur, 1, 135-139. (In Russ.)].

Солопова О.А., Чудинов А.П. Диахронический анализ метафор в британском корпусе текстов: колокола победы и Russia's V-Day // Вестник Российского университета дружбы народов. Серия: Лингвистика. 2018. Т. 22. № 2. С. 313-337. [Solopova, Olga and Chudinov, Anatoly (2018). Diachronic Analysis of Political Metaphors in the British Corpus: from Victory Bells to Russia's V-Day. In Russian Journal of Linguistics, 22 (2), 313-337. (In Russ.)]. https://doi.org/10.22363/2312-9182-2018-22-2-313-337.

Тоффлер Э. Шок будущего / пер. с англ. Е. Руднева, Л. Бурмистрова, К. Бурмистров, И. Москвина-Тарханова, А. Микиша, А. Мирер, В. Кулагина-Ярцева, Н. Хмелик, Е. Комарова. M.: ACT, 2013. 344 c. [Toffler, Alvin (2013). Shok budushchego [Future Shock] / transl. by E. Rudneva, L. Burmistrova, K. Burmistrov, I. Moskvina-Tarkhanova, A. Mikisha, A. Mirer, V. Kulagina-Yartseva, N. Khmelik, E. Komarova. Moscow: AST. (In Russ.)].

Черткова Е. Утопия как тип сознания // Общественные науки и современность. 1993. № 3. C. 71-81. [Chertkova, E. (1993). Utopiya kak tip soznaniya [Utopia as a Type of Conscience]. In Obshchestvennye nauki i sovremennost', 3, 71-81. (In Russ.)].

Шацкий Е. Утопия и традиция / пер. с польск. В.А. Чаликовой. М.: Прогресс, 1990. 455 с. [Szacki, Ezhi (1990). Utopiya i traditsiya (Utopia and Traditions / Utopie + Tradycja: Przegląd Problematyki) / transl. by V.A. Chalikova. Moscow: Progress. (In Russ.)]. 
Юсупова Т.С. Структурные особенности военного дискурса // Известия Самарского научного центра Российской академии наук. 2009. Т. 11. Вып. 4. С. 1055-1057. [Yusupova, Tatiana S. (2009). Strukturnye osobennosti voennogo diskursa (Structural Features of Military Discourse). In Izvestiya Samarskogo nauchnogo tsentra Rossiiskoi akademii nauk, 11, 4, 10551057. (In Russ.)].

Ainsa, Fernando (1990). Necesidad de la utopía. Buenos-Aires y Montevideo: Tupac \& Nordan.

Bloch, Ernst (2000). The spirit of Utopia. California; Stanford: Stanford University Press.

Chronicling America: The National Endowment for the Humanities and the Library of Congress // Internet Archive [official website]. URL: https://chroniclingamerica.loc.gov (mode of access: 25.09.2018).

Dahrendorf, Ralf Gustav (1967). Pfade aus Utopia: Arbeiten zur Theorie und Methode der Soziologie. München: Piper \& Co. Verlag.

Duran, Juan Guillermo (1972). Literatura y utopía en Hispanoamérica. N.Y.: Cornell University.

Gavriely-Nuri, Dalia. Mythic Metaphors and Cultural Codes In the Israeli Peace Discourse. In Journal of Language and Politics. Amsterdam / Philadelphia: John Benjamins Publishing, 2010, 3, 449-468. https://doi.org/10.1075/jlp.9.3.06gav.

Gallica: la Bibliothèque nationale de France et de ses partenaires // [official website]. URL: http://gallica.bnf.fr. (mode of access: 25.09.2018).

Lakoff, George. Metaphor and war: The Metaphor System Used to Justify War in the Gulf. In Peace Research. Mantoba; Canadian Mennonite University: CMU Press, 1991, 23.2 (3), 25-32.

Lasky, Melvin (1976). Utopia and revolution. Chicago: The University of Chicago Press.

Masalha, Nur (2003). The Politics of Denial: Israel and the Palestinian Refugee Problem. London: Pluto Press. https://doi.org/doi: 10.2307/j.ctt18dztmq.

Mollin, Sandra. The Use of Face-Threatening Acts in the Construction of In- and Out-Group Identities in British Parliamentary Debates. In The Discursive Construction of Identities On- and Offline. Amsterdam / Philadelphia: John Benjamins Publishing, 2018, 205-226. https://doi.org/ 10.1075/dapsac.78.09mol.

Solopova, Olga A. Metaphor in Modeling the Future: The Best-Case Scenario (Based on Political Discourses of Russia, the USA and Great Britain, the 21st Century). In Vestnik Tomskogo Gosudarstvennogo Universiteta, 2017, 46, 55-70. https://doi.org/10.17223/19986645/46/5.

Solopova Olga A., Saltykova, Maria S., Voroshilova, Maria B. (2018). Internet Archiving: The Use in Discourse Studies. In NORDSCI Proceedings, 301-309. https://doi.org/10.32008/ NORDSCI2018/B1/V1/1.

Starr, Harvey, Dubinsky, Stanley (2015). The Israeli Conflict System: Analytic Approaches. In Routledge Studies in Middle Eastern Politics. London / New York: Routledge.

The British Newspaper Archive // Internet Archive [official website]. URL: https://www.british newspaperarchive.co.uk (mode of access: 25.09.2018).

Tillich, Paul (1973). Critique and Justification of Utopia. In Utopias and Utopian Thought. Eds. by Frank Edward Manuel. London: Souvenir Press, 296-309.

\section{Article history:}

Received: 16 January 2019

Revised: 01 March 2019

Accepted: 17 March 2019 


\section{История статьи:}

Дата поступления в редакцию: 16 января 2019

Дата принятия к печати: 17 марта 2019

\section{Bionotes:}

OLGA A. SOLOPOVA is Ph.D. (Advanced Doctorate) in Philology, Professor at the Institute of Linguistics and International Communications of the South Ural State University (National Research University). Her research interests include linguistic political prognostics, discourse analysis and diachronic political metaphor studies.

Contact information: e-mail: o-solopova@bk.ru.

MARIA S. SALTYKOVA is Ph.D. in Philology, Associate Professor at the Institute of Linguistics and International Communications of the South Ural State University (National Research University). Her research interests include discourse analysis, media discourse and linguistic political prognostics.

Contact information: e-mail: marie-s@mail.ru.

\section{Сведения об авторах:}

ОЛЬГА АЛЕКСАНДРОВНА СОЛОПОВА — доктор филологических наук, профессор кафедры лингвистики и перевода института лингвистики и международных коммуникаций, ФГАОУ ВО Южно-Уральский государственный университет (Национальный исследовательский университет). Сфера научных интересов: лингвополитическая прогностика, дискурсология, диахроническая политическая метафорология.

Контактная информация: e-mail: o-solopova@bk.ru

МАРИЯ СЕРГЕЕВНА САЛТЫКОВА - кандидат филологических наук, доцент кафедры лингвистики и перевода института лингвистики и международных коммуникаций, ФГАОУ ВО Южно-Уральский государственный университет (Национальный исследовательский университет). Сфера научных интересов: дискурсология, медийный дискурс, лингвополитическая прогностика.

Контактная информация: e-mail: marie-s@mail.ru. 